\title{
Adipose energy stores, physical work, and the metabolic syndrome: lessons from hummingbirds
} James L Hargrove*

\author{
Address: Department of Foods and Nutrition, University of Georgia, Athens, GA 30605, USA \\ Email: James L Hargrove* - jhargrov@fcs.uga.edu \\ * Corresponding author
}

Published: 13 December 2005

Nutrition Journal 2005, 4:36 doi:10.1/86//475-289/-4-36

This article is available from: http://www.nutritionj.com/content/4/I/36

(C) 2005 Hargrove; licensee BioMed Central Ltd.

This is an Open Access article distributed under the terms of the Creative Commons Attribution License (http://creativecommons.org/licenses/by/2.0), which permits unrestricted use, distribution, and reproduction in any medium, provided the original work is properly cited.
Received: 14 June 2005

Accepted: 13 December 2005

\begin{abstract}
Hummingbirds and other nectar-feeding, migratory birds possess unusual adaptive traits that offer important lessons concerning obesity, diabetes and the metabolic syndrome. Hummingbirds consume a high sugar diet and have fasting glucose levels that would be severely hyperglycemic in humans, yet these nectar-fed birds recover most glucose that is filtered into the urine. Hummingbirds accumulate over $40 \%$ body fat shortly before migrations in the spring and autumn. Despite hyperglycemia and seasonally elevated body fat, the birds are not known to become diabetic in the sense of developing polyuria (glucosuria), polydipsia and polyphagia. The tiny ( $3-4 \mathrm{~g}$ ) Ruby-throated hummingbird has among the highest mass-specific metabolic rates known, and loses most of its stored fat in $20 \mathrm{~h}$ by flying up to 600 miles across the Gulf of Mexico. During the breeding season, it becomes lean and maintains an extremely accurate energy balance. In addition, hummingbirds can quickly enter torpor and reduce resting metabolic rates by 10 -fold. Thus, hummingbirds are wonderful examples of the adaptive nature of fat tissue, and may offer lessons concerning prevention of metabolic syndrome in humans.
\end{abstract}

Recent emphasis on human obesity obscures the fact that fat cells and the triglyceride energy system provide crucial functions in animals as diverse as invertebrate worms $(C$. elegans)[1], insects including fruit flies (D. melanogaster)[2], bony fish [3], toads (Bufo species), lizards [4], and birds [5]. Plainly, fat tissue did not originate merely as a cause of disease in sedentary people. It is part of an ancient, genetically inherited energy regulatory system in most if not all animal species. In many animals, day length and season strongly affect fat deposition through mechanisms that involve changes in pineal function, activation of the sympathetic nervous system, and changes in sensitivity to peptides such as leptin and neuropeptide Y $[6,7]$. Studies of seasonal weight gain offer insights into human obesity, and there may be a seasonal component in the development of human obesity in temperate regions[8].

The adaptive value of fat in providing energy for work, reproduction and survival is dramatized in the migratory energetics of the Ruby-throated hummingbird (Archilocus colubris), a bird which is familiar to most people who reside in eastern North America and Central America. The amount of fat (1-2g) that would allow a human to climb about 50 feet is enough for the Ruby-throat to fly across the Gulf of Mexico, and failure to make the crossing would mean certain death. This paper will review aspects of hummingbird energetics and seasonal weight regulation that may be unfamiliar to students of human obesity. 


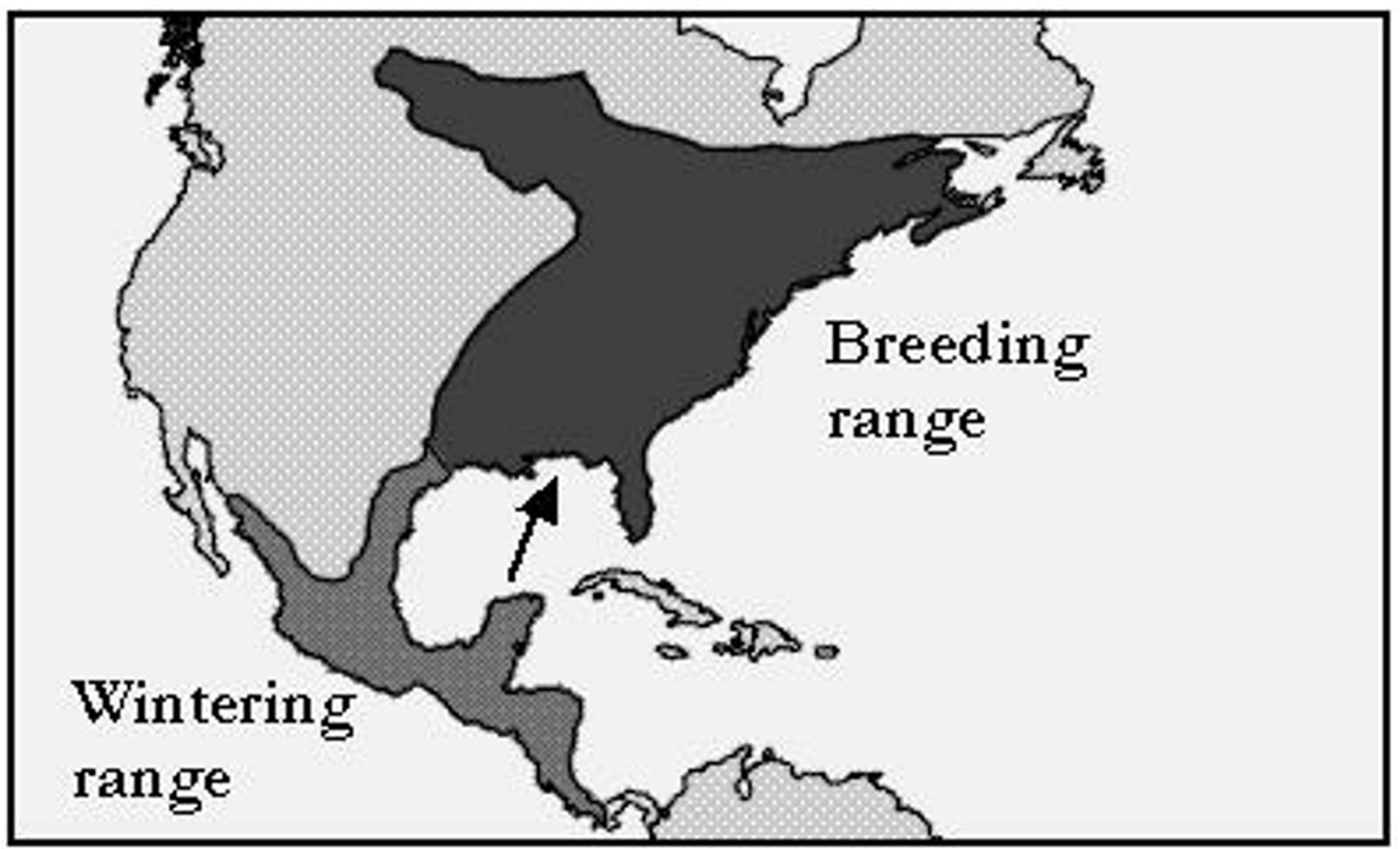

Figure I

Approximate wintering range and breeding range of the Ruby-throated hummingbird. Arrow indicates a probable migratory pathway from Yucatan to the southern U.S.

\section{Biology of the Ruby-throated Hummingbird}

The hummingbird family (Trochilidae) includes some of the smallest and most metabolically active vertebrates, with the Bumblebee hummingbird weighing under 2.0 grams [9]. At 2.5-4.8 g, the adult Ruby-throated hummingbird weighs much less than the common shrew and a little more than a U.S. penny (2.5 g). During mid-summer, females average about $3.3 \mathrm{~g}$ compared to $3.0 \mathrm{~g}$ for males [9]. Both genders contain an average of about $21 \%$ body fat (0.47-0.58 g) when not migrating [10]. The higher body weights are observed just prior to migration when the birds stop nesting and feed actively. The birds gain an additional $\sim 1.7 \mathrm{~g}$ of fat and double their percent body fat prior to migration [11]. A. colubris spends the winter in Central America and migrates to North America for the breeding season, going as far north as Ontario, Canada (Fig. 1). The total trip may exceed 2000 miles, and is reversed in the fall. The migrations are timed to coincide with the blossoming of several flowering plants, which provide nectar that fuels much of the journey. Nectars contain as much as 38\% ( 1 M) sugars (mostly sucrose) $[12,13]$. After fasting overnight, hummingbirds primarily metabolize free fatty acids and have a respiratory quotient
(RQ) of about 0.7. However, the RQ quickly goes to about 1.0 when they begin to feed, indicating oxidation of carbohydrate $[14,15]$. During the breeding season, males maintain an extremely accurate body mass by ingesting small meals roughly every 15-20 $\mathrm{min}$, and using the energy to court females and chase away other males [16]. Just before nightfall, they consume enough nectar to last the night; when that fails, they may enter torpor to conserve energy $[15,17]$.

Hummingbirds have one of the highest metabolic rates relative to metabolic body size of any animal on earth. Heart rates up to 1260 beats per minute have been recorded, and breathing rate is about 250 breaths per minute even at rest. Resting body temperatures are about $39^{\circ} \mathrm{C}[9]$. At rest, oxygen consumption is about $4 \mathrm{ml} \mathrm{O} /$ $\mathrm{g} / \mathrm{h}$ [18]. During flight, hummingbird oxygen consumption per gram of muscle tissue is approximately 10 times higher than that seen for elite human athletes [19].

Preparation for migration requires that the birds switch from carbohydrate to fat metabolism during flight, and this entails changes in feeding behavior, energy storage 


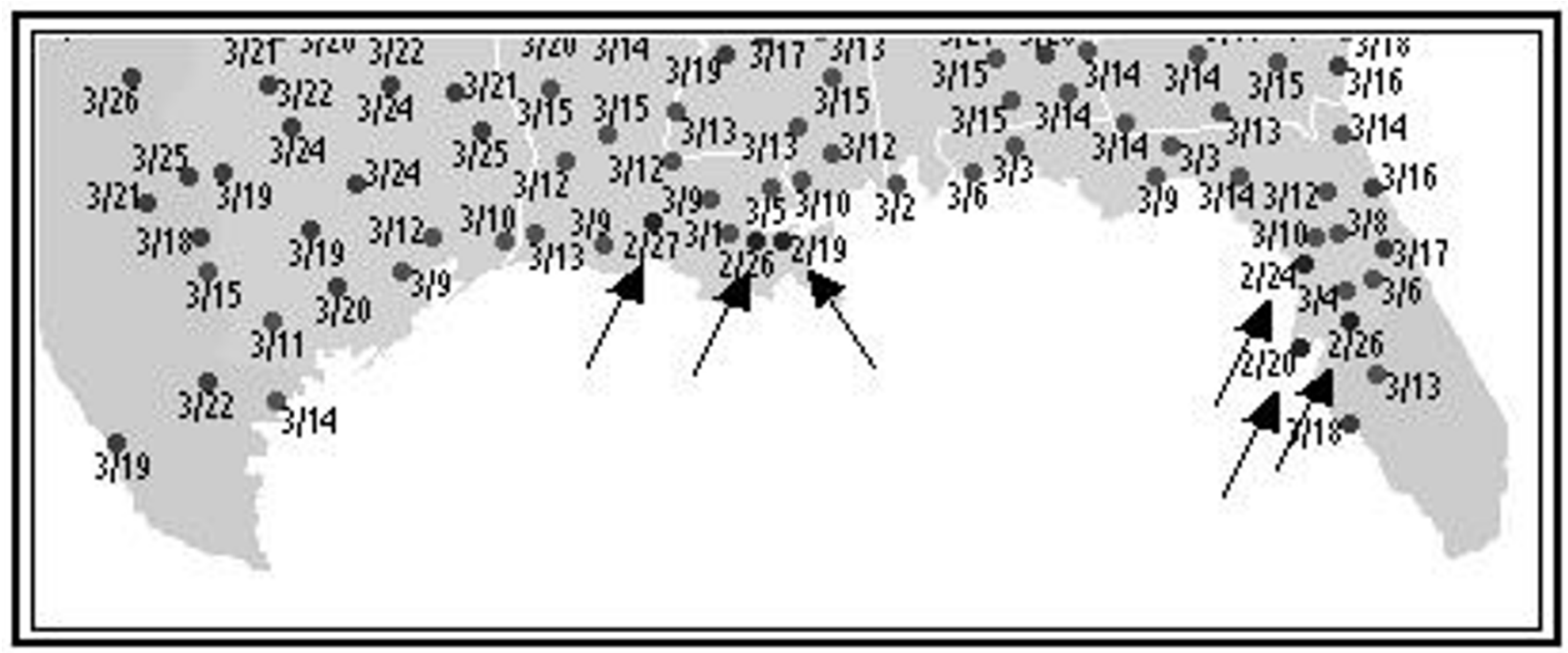

Figure 2

First Spring sightings of Ruby-throated hummingbirds in 2005 occurred during February in Louisiana and Florida (arrows) before the birds had been reported in Texas. Source: Hummingbirds.net http://www.hummingbirds.net/map.html\#south.

and mitochondrial energy usage. During periods of rapid fattening, hummingbird RQ values are above 1.0, consistent with lipogenesis or at least fat storage. The mechanisms of fattening include increased energy intake, increased food efficiency, altered diet selection, and increased lipogenic enzymes [20]. Preferential metabolism of carbohydrate spares lipids for storage. Hummingbirds do eat insects and they may increase insect consumption prior to migration [21,22].

Hummingbirds [13,23] and many other birds [5,24] maintain very high blood glucose both in the fasted and fed conditions. In hummingbirds, fasted glucose is about $17 \mathrm{mM}$ (300 mg/dl), and it increases to about $42 \mathrm{mM}$ (740 mg/dl) after feeding [23,25]. Although these levels would be classified as diabetic in humans, nectivorous birds do not become diabetic $[13,26]$ in the traditional sense of spilling glucose into the urine with symptoms of polyuria, polydipsia and polyphagia. Also, they do not develop the degree of glycated hemoglobin seen in humans [23]. Migrating birds may become insulin resistant and there may be a parallel to human metabolic syndrome [27]. However, the birds are forced to switch from almost total reliance on carbohydrate to almost total reliance on fatty acid metabolism during migration over oceans or desert terrain that provides no other energy sources.

\section{Hummingbird Energetics: Across the Gulf of Mexico on a Gram of Fat}

During the northward migration, many ruby-throated hummingbirds reach the Gulf of Mexico on the coast of
Yucatan. The distance to the U.S. can equal 500-600 miles, and the most direct routes provide no sites at which food or water may be obtained. Whereas some birds may take a coastal route or possibly fly to Cuba, ornithologists believe that most birds fly non-stop across the Gulf of Mexico [9]. Networks of bird-watchers report data on various species during the migrations, and it is noteworthy that arrivals may be reported in Louisiana and Florida prior to arrivals in Texas (Fig. 2). Males arrive in the U.S. prior to the females, and time is critical because the birds compete for habitat. A premium may be placed on early arrival because it provides selective advantage in breeding. Prior to departing, the birds must store enough energy to fly at speeds that range from 25-50 mph.

Pearson [28] measured oxygen consumption of 2 species of hummingbird during hovering flight and found values of 68-85 $\mathrm{ml} \mathrm{O}_{2} / \mathrm{g} / \mathrm{hr}$. He calculated a flight range of 385 miles on the assumption that the birds stored $1 \mathrm{~g}$ of fat and consumed $80 \mathrm{ml} \mathrm{O}_{2} / \mathrm{g} / \mathrm{hr}$ (caloric equivalent of 4.69 $\mathrm{kcal} / \mathrm{l}$ ) when flying at $50 \mathrm{mph}$. However, Odum et al [11] showed that Ruby-throated hummingbirds can store more than $40 \%$ of body weight as fat, and found a mean content of fat of $2.25 \mathrm{~g}$ in birds accidentally killed at television towers. Lasiewski [29] showed that the metabolic rate is probably lower ( $42 \mathrm{cc} . \mathrm{O}_{2} / \mathrm{gm} / \mathrm{hr}$ ) than Pearson estimated. Assuming a flight speed of $25 \mathrm{mph}$, he estimated that males have a flight range of about 650 miles while females have a range of about 610 miles. The highest estimate of flight range for the Ruby-throated hummingbird is about $2500 \mathrm{~km}$ (1500 miles) [11]. 
If one assumes an average flight weight of $3.5 \mathrm{~g}$ and a caloric equivalent of $4.69 \mathrm{kcal} / \mathrm{l}$, then the energy needed for crossing the Gulf of Mexico is about $0.7 \mathrm{kcal}$ per hour. A 20 hour crossing would require about $14 \mathrm{kcal}$, or $1.5 \mathrm{~g}$ of fat (1.8 $\mathrm{g}$ of fat tissue assuming that fat tissue contains $7.7 \mathrm{kcal} / \mathrm{g}$ ). If the birds were to rely on glycogen for this energy, they would need to store about $3.5 \mathrm{~g}$ of carbohydrate. Adding $2 \mathrm{~g}$ of water of hydration for each $\mathrm{g}$ of glycogen, the birds would have to increase their body weight to above $10 \mathrm{~g}$ ! The flight is possible only because the energy yield per gram of fat is 10 fold higher than for hydrated glycogen [19]. If they relied on glycogen, it is unlikely that the birds could generate sufficient lift to leave Yucatan, much less carry the extra weight across the Gulf of Mexico [22].

\section{Conclusion}

Migrating birds stay lean until pre-migratory fattening becomes necessary, and then may add fat at a rate of $1-$ $13 \%$ of body weight per day [27]. For Ruby-throated hummingbirds, the fattening is crucial for survival. The average "field metabolic rate" is about 8 times resting metabolic rate [30], and during constant flight, hummingbirds expend about $0.7 \mathrm{kcal} / \mathrm{hr}[18,29]$. Glucose at $42 \mathrm{mM}$ distributed in blood and extracellular fluid $(20 \%$ of body weight) would provide $6 \mathrm{mg}$ of glucose ( 24 calories or 100 $\mathrm{J})$. This is sufficient only for a few minutes of flight. The birds would quickly shift to metabolism of glycogen and fatty acids to provide adequate energy. Thus, the premigratory fattening is purposive, and a typical flight across the Gulf of Mexico will require about $75 \%$ of the birds' energy stores (assuming that $1.5 \mathrm{~g}$ of fat is used out of $\sim 2.0 \mathrm{~g}$ stored).

The first lesson that the Ruby-throated hummingbird teaches is that becoming fat can be beneficial if it is necessary as an energy buffer to survive. The second lesson is that fat birds with very high plasma glucose levels do not become diabetic. Part of the preventative mechanism is anatomical and physiological. Nectar feeding birds are unusual in that they consume large amounts of water along with the sugars they typically consume [26]. Birds have a relatively low glomerular filtration rate and are able to reabsorb essentially all of the glucose that is filtered into the urine [26]. It is not clear how they avoid showing symptoms of "glucose toxicity" such as glycated hemoglobin, but the levels of hemoglobin A1c are lower than in humans [23]. One hypothesis could be that the turnover rates of red blood cells and proteins are substantially higher in birds than in mammals. For example, the lifespan of red blood cells in birds can be 21 days or less vs. about 120 days for humans[31], so there may be less opportunity for glycation. Turnover rates for metabolic pools are thought to be proportional to body mass to the $1 / 4$ power [32], which would indicate that metabolic pools exchange about 12 times faster in hummingbirds than in humans (Kleiber, p. 216 and 390). This is congruent with the high ATP turnover rate in active muscle [33]. Whether or not birds avoid obesity and diabetes by dint of their rates of living, the neurobiology and endocrinology of avian fat deposition are complex, and students of migratory birds have suggested that they could offer important clues concerning prevention of obesity and diabetes in humans $[26,27]$.

Diabetes and the metabolic syndrome are rightfully considered to be kinetic disorders that do not develop unless several major controls fail. Typically, sensitivity to insulin and to glucose ("glucose effectiveness") both diminish, creating insulin resistance [34]. Hepatic glucose production may continue (instead of shutting off) even if plasma glucose and insulin are both elevated. The rate of production of insulin by the beta cell must also fail to compensate for the decreased sensitivity [34]. These are conditions that come about in humans because of sedentary habits and obesity [35]. In migrating birds, there may be a decline in insulin sensitivity, but it is unlikely that regulation of beta cell function or hepatic glucose production becomes abnormal. Hummingbirds combat kinetic disorders by dint of their highly aerobic lifestyles and necessity of maintaining close feedback between energy intake and energy expenditure. Unlike humans who have "uncoupled" food intake from functional needs, animals that must flap their wings at 50 beats per second in order to feed have a hard time staying fat.

\section{Competing interests}

The author(s) declare that they have no competing interests.

\section{Authors' contributions}

This review was prepared entirely by Dr. Hargrove.

\section{Acknowledgements}

The author thanks Dr. Cameron B. Kepler (Athens, GA) for discussing the energetics of avian migration. The work was supported by funds from Hatch Project GEO00922, US Agricultural Experiment Station.

\section{References}

I. McKay RM, McKay JP, Avery L, Graff JM: C elegans: a model for exploring the genetics of fat storage. Dev Cell 2003, 4:|3|-|42.

2. Hwangbo DS, Gershman B, Tu MP, Palmer M, Tatar M: Drosophila dFOXO controls lifespan and regulates insulin signalling in brain and fat body. Nature 2004, 429:562-566.

3. Albalat A, Liarte C, MacKenzie S, Tort L, Planas JV, Navarro I: Control of adipose tissue lipid metabolism by tumor necrosis factor-alpha in rainbow trout (Oncorhynchus mykiss). J Endocrinol 2005, 184:527-534.

4. Migliorini RH, Lima-Verde JS, Machado CR, Cardona GM, Garofalo $M A$, Kettelhut IC: Control of adipose tissue lipolysis in ectotherm vertebrates. Am J Physiol 1992, 263:R857-62.

5. Bairlein F, Simons D: Nutritional Adaptations in Migrating Birds. Israel Journal of Zoology 1995, 41:357-367.

6. Bartness TJ, Demas GE, Song CK: Seasonal changes in adiposity: the roles of the photoperiod, melatonin and other hor- 
mones, and sympathetic nervous system. Exp Biol Med (Maywood) 2002, 227:363-376.

7. Adam CL, Mercer JG: Appetite regulation and seasonality: implications for obesity. Proc Nutr Soc 2004, 63:4I 3-4I9.

8. Visscher TL, Seidell JC: Time trends (1993-1997) and seasonal variation in body mass index and waist circumference in the Netherlands. Int J Obes Relat Metab Disord 2004, 28:1309-1316.

9. Johnsgard PA: The Hummingbirds of North America. 2nd edition. Washington, D.C., Smithosonian Institution Press; 1997:278 PP.

10. Connell CE, Odum EP, Kale H: Fat-free weights of birds. Auk 1960, 77:1-9.

II. Odum EP, Connell CE, Stoddard: Flight Energy And Estimated Flight Ranges Of Some Migratory Birds. Auk 196I, 78:5I5-527.

12. Galetto L, Bernardello G: Floral nectaries, nectar production dynamics and chemical composition in six ipomoea species (convolvulaceae) in relation to pollinators. Ann Bot (Lond) 2004, 94:269-280.

13. McWhorter T], Martinez del Rio C: Food ingestion and water turnover in hummingbirds: how much dietary water is absorbed? J Exp Biol 1999, 202 (Pt 20):285I-2858.

14. Suarez RK, Lighton JR, Moyes CD, Brown GS, Gass CL, Hochachka PW: Fuel selection in rufous hummingbirds: ecological implications of metabolic biochemistry. Proc Natl Acad Sci U S A 1990, 87:9207-9210

15. Powers DR: Diurnal-Variation in Mass, Metabolic-Rate, and Respiratory Quotient in Anna and Costa Hummingbirds. Physiological Zoology 1991, 64:850-870.

16. Calder WA, Calder LL, Frazier TD: The hummingbird's restraint: a natural model for weight control. Experientia 1990, 46:999-1002.

17. Hiebert S: Seasonal-Changes in Body-Mass and Use of Torpor in a Migratory Hummingbird. Auk 1993, I l 0:787-797.

18. Lasiewski RC: Oxygen consumption of torpid, resting, active and flying hummingbirds. Physiological Zoology 1963, 36:122-140.

19. Suarez RK: Hummingbird Flight - Sustaining the Highest Mass-Specific Metabolic Rates among Vertebrates. Experientia 1992, 48:565-570.

20. Bairlein F, Gwinner E: Nutritional mechanisms and temporal control of migratory energy accumulation in birds. Annual Review of Nutrition 1994, 14:187-215.

21. Yanega GM, Rubega MA: Feeding mechanisms: Hummingbird jaw bends to aid insect capture. Nature 2004, 428:6I5.

22. Altshuler DL, Dudley R: The ecological and evolutionary interface of hummingbird flight physiology. J Exp Biol J Exp Biol 2002, 205:2325-2336.

23. Beuchat $C A$, Chong $C R$ : Hyperglycemia in hummingbirds and its consequences for hemoglobin glycation. Comp Biochem Phys A Comp Biochem Phys A 1998, I 20:409-416.

24. Bairlein F: Seasonal-Variations of Serum Glucose-Levels in a Migratory Songbird, Sylvia-Borin. Comp Biochem Phys A Comp Biochem Phys A 1 983, 76:397-399.

25. Beuchat CA, Chong CR: Hyperglycemia in hummingbirds: Implications for hummingbird ecology and human health. Faseb Journal 1997, I I:529-529.

26. McWhorter TJ, Martinez del Rio C, Pinshow B, Roxburgh L: Renal function in Palestine sunbirds: elimination of excess water does not constrain energy intake. J Exp Biol 2004, 207:3391-3398.

27. Bairlein F: How to get fat: nutritional mechanisms of seasonal fat accumulation in migratory songbirds. Naturwissenschaften 2002, 89: $1-10$.

28. Pearson O: The metabolism of hummingbirds. Condor 1950, 52:145-II52.

29. Lasiewski RC: The energetics of migrating hummingbirds. The Condor 1964, 64:324.

30. Powers DR, Conley TM: Field metabolic-rate and food-consumption of 2 sympatric hummingbird species in southeastern Arizona. Condor 1994, 96:141-150.

31. Kalomenopoulou M, Koliakos G: Total body haematocrit iron kinetics and erythrocyte life span in pigeons (Columba livia). Comp Biochem Physiol A 1989, 92:215-218.

32. Kleiber M: The Fire of Life, An Introduction to Animal Energetics. New York: Huntington, Robert Kreiger; 1975:453.

33. Suarez RK: Upper limits to mass-specific metabolic rates. Annual Review of Physiology 1996, 58:583-605.
34. Bergman RN, Watanabe R, Rebrin K, Ader M, Steil G: Toward an integrated phenotype in pre-NIDDM. Diabet Med 1996, 13:S67-77.

35. Esparza J, Fox C, Harper IT, Bennett PH, Schulz LO, Valencia ME, Ravussin E: Daily energy expenditure in Mexican and USA Pima indians: low physical activity as a possible cause of obesity. Int J Obes Relat Metab Disord 2000, 24:55-59.
Publish with Bio Med Central and every scientist can read your work free of charge

"BioMed Central will be the most significant development for disseminating the results of biomedical research in our lifetime. "

Sir Paul Nurse, Cancer Research UK

Your research papers will be:

- available free of charge to the entire biomedical community

- peer reviewed and published immediately upon acceptance

- cited in PubMed and archived on PubMed Central

- yours - you keep the copyright 